\title{
Analysis of the factors of forming customer loyalty: regional aspects
}

\author{
Oksana V. Golub \\ Volgograd State University \\ Institute of history, international affairs and social \\ technologies \\ Volgograd, Russia \\ golub@volsu.ru
}

\author{
Tatiana S. Timofeeva \\ Volgograd State University \\ Institute of history, international affairs and social \\ technologies \\ Volgograd, Russia \\ timofeeva@volsu.ru
}

\author{
Olga F. Serova \\ Volgograd State University \\ Institute of Management and Regional Economics \\ Volgograd, Russia \\ serova.o@volsu.ru
}

\begin{abstract}
Customer loyalty is one of the criteria which determine the efficiency of a modern company. To develop loyalty programmes, it is necessary not only to investigate the style of consumer preferences, but also to reveal the power of influence of the factors shaping it. The style of consumer preferences can be described with the help of a two-component model which includes basic motives of human behaviour and strategies for their implementation. With the help of this model, two key consumer styles - constructive and adaptive (protective) - were defined as well as their varieties. The next step of the research involved identifying factors which influence consumer choice, selecting a range of methods and techniques, creating a sample. Materials of the empirical study made it possible to assess the effect of these factors on consumer behaviour of the residents of the Volgograd and Astrakhan regions. The obtained results imply the fact that most consumers in the region are oriented towards keeping to constructive styles. It means that developing loyalty programmes should be performed with due regard for both rational (those concerning functional attributes of goods) and emotional arguments (prospects of selfdevelopment by means of using goods, adhering to consumer values, communicating within a certain group of consumers).
\end{abstract}

Keywords - loyalty, style of consumer behaviour, sociopsychological factors, consumer preferences, motives of human behaviour

\section{INTRODUCTION}

Consumer loyalty based on the positive experience of purchasing and using a product is one of the factors determining the efficiency of the company. At present, there are lots of approaches to defining the term "consumer loyalty." The most common is its interpretation in relation with consumes' preference of a particular product (service), brand or a factory. The components of loyalty are satisfaction, devotion of a consumer, his/her eagerness to recommend the product, brand or the factory to other people. Before developing loyalty programmes it is necessary to obtain a detailed portrait of a target consumer, based on the factors shaping his/her preferences.

The idea of consumer behaviour and the properties of its manifestation are considered in the works of E. P. Ilyin [1], F. Kotler [2], O. T. Melnikov, Y. E. Shirkov, T. V. Folomeev [3], O. S. Posypanova [4], A. T. Stephen [5], R. A. Peterson, U. N. Umesh [6], H. Hayakawa, Y. Venieris [7], B. Mittal [8], P. Rodríguez-Torrico, R. S. J. Cabezudo, S. San-Martín [9], A. R. Kamaruddin, K. Kamaruddin [10]. The problems of forming loyalty were studied by I.V. Arakelova, E.M. Prasyan, L.S.Shakhovskaya [11]. Practice of describing situations of making a purchase decision makes it possible to depict styles of consumer behaviour. Style of consumer behaviour is a combination of external (culture, mass media, society, group) and internal (values, attitudes, personal traits) components in the consumer behaviour model which determine peculiarities and approaches to perceivable and unconscious motives and wants of an individual. Including socio-psychological factors in economic research is caused by cross-disciplinary logic of scientific knowledge [12, 13].

\section{MAterials AND MethodS (MODEL)}

The research paper displays a two-component model of consumer behaviour styles which includes basic motives of human behaviour and strategies for their implementation.

The basic motives are the needs to overcome existential fears (the fear of loss of affiliation, control and status). Coping with fears occurs in two ways: constructive (based on real wants and values of van individual) and adaptive (based on functioning of defense mechanisms). 
Consumer motives presented in table 1 have influence on strategies of consumer behaviour. Thus, the fear of loss of control, status or trust-based relations results in forming a certain type of consumption aimed at giving the desired impression on the others, very often at the price of one's own interests and material welfare. This kind of behaviour is characteristic of the adaptive style whereas for the consumers with the constructive style objective qualities of goods and services, their features and price are of utmost importance. Styles of consumer behaviour are the very model which is open to observation and, consequently, to forecasting and control.

TABLE I. CONSUMER BeHAVIOUR STYLES

\begin{tabular}{|c|c|c|}
\hline \multirow{2}{*}{$\begin{array}{c}\text { Basic } \\
\text { motives }\end{array}$} & \multicolumn{2}{|c|}{ Strategy of implementation of motives } \\
\hline & Constructive & Adaptive (Protective) \\
\hline Affiliation & $\begin{array}{l}\text { purchasing and using only } \\
\text { those goods and services } \\
\text { which let it possible to } \\
\text { experience affiliation with } \\
\text { other people, to make family } \\
\text { members happy, socialize, be } \\
\text { in contact with near and dear }\end{array}$ & $\begin{array}{l}\text { purchasing in order not to } \\
\text { be a pariah, trying to look } \\
\text { more attractive (it is } \\
\text { estimated that } \\
\text { companionship and love } \\
\text { can be bought, there is no } \\
\text { need in close relations) }\end{array}$ \\
\hline Control & $\begin{array}{l}\text { consuming those goods and } \\
\text { services which are necessary } \\
\text { in certain conditions with due } \\
\text { regard to public policy; an } \\
\text { individual takes responsibility } \\
\text { for his/her own life } \\
\text { effectiveness }\end{array}$ & $\begin{array}{l}\text { the key aspect of } \\
\text { consumption is the desire } \\
\text { to gain control of other } \\
\text { people, make value } \\
\text { judgments, criticize, } \\
\text { demonstrate grip, } \\
\text { manipulate other people's } \\
\text { lives being unable to be } \\
\text { responsible for one's own } \\
\text { life }\end{array}$ \\
\hline Status & $\begin{array}{l}\text { consuming aimed at realizing } \\
\text { the need of positive } \\
\text { evaluation, respect, } \\
\text { recognition and care, } \\
\text { meanwhile consumption } \\
\text { corresponds to actual status, } \\
\text { material well-being; self- } \\
\text { esteem is adequate }\end{array}$ & $\begin{array}{l}\text { fixation on showing off, } \\
\text { using brand goods only } \\
\text { for the fear of being } \\
\text { excluded from elite group; } \\
\text { living on a budget, low } \\
\text { self-esteem; actual social } \\
\text { status doesn't satisfy an } \\
\text { individual }\end{array}$ \\
\hline $\begin{array}{l}\text { General } \\
\text { descriptio } \\
n \text { of style }\end{array}$ & $\begin{array}{l}\text { "be", "use" - remain true to } \\
\text { oneself, not to contradict one's } \\
\text { values; consumption is } \\
\text { determined by practical } \\
\text { usefulness of goods or services }\end{array}$ & $\begin{array}{l}\text { "seem", "possess"- } \\
\text { consume in order to look } \\
\text { more successful and } \\
\text { popular even if it is } \\
\text { harmful to one's well- } \\
\text { being }\end{array}$ \\
\hline
\end{tabular}

The table has been composed according to [14, p. 7].

Forming of consumer behaviour styles depends on the following factors: social roles, types of activity, identity, age and gender peculiarities, attitudes, values and directions in thinking. Some of them (similarity with representatives of a certain subculture, type of professional occupation) have outward appearances (for example, people doing professional sports prefer track wear; reveal devotion to rock music; they often demonstrate presence of trappings of a given subculture in clothing and hairstyle). Other factors can't be interpreted without alternative and require empirical testing.

Each of these factors determines to one extent or another possibility of consumer choice. Problem number one at present is to assess the power of influence of psychological factors on forming consumer loyalty. The research "Psychological Structure of Consumer Behaviour Styles" which was conducted on the territory of the Volgograd and Astrakhan regions in 2012-2016 has given rise to solving this problem.

The following independent invariables were distinguished: psychological traits of a consumer (age, phases of consumer preferences, personal traits and individual type, subjective economic well-being, perfectionistic attitudes). Also, consideration of social roles through the gender disaggregation was completed. Dependent variable is consumer behaviour style (as an indicator of the stable model which predicts and identifies consumer behaviour). The research presents both total consolidated figure concerning constructive and adaptive styles and figures on every single scale.

To evaluate psychological components, a psychodiagnostic package was gathered up (The Myers-Briggs questionnaire (MBTI), test "Big five" (personality traits, thinking, socializing); test by R. Assagioli (values), "Multidimensional scale of perfectionism" (MSP) by P. Hewitt and G. Flett (perfectionistic attitude).

The sample group included 280 residents of Volgograd and the Volgograd and Astrakhan regions, its formation was based on random strata-bound selection. The following criteria were taken into account: age (17 to 65 year-olds), sex (114 males and 166 females), level of material of material prosperity (below poverty level (6.628 rub.), medium income for the region (up to 22.172 rub.), above-average earnings for the region (exceeding 22.172 rub.)

The obtained data were processed with the programme SPSS Statistics22. As a basic method of parametric data analysis "ANOVA" (single-factor analysis of variance) was used. This method helps to compare three or more sample groups (characterizing the levels of independent variable) according to the mean values of the dependent variable and to reveal the power of factor $(F)$. The higher this index, the stronger the influence of the independent variable on the dependent one.зависимую.

\section{RESULTS AND DISCUSSION}

The results of the research allowed us to point out the most significant factors determining people's inclination for preference either for adaptive or constructive styles of consumer behaviour.

\section{A. Influence of age peculiarities on the style of consumption.}

The period of adulthood is essential for determining consumer loyalty. The age itself doesn't dominate style of consumption, but it is closely connected with the individual's income and personal traits, which is reflected in particular properties of consumer behaviour. At the age of 17 to 23 consumer preferences of an individual are developing although the financial situation is not stable. Between the ages of 23-45 a person is gaining professional skills, his career is developing; his consumer preferences are getting settled. During the period of late adulthood reduction of consumer preferences can be observed. In other words, the amount of 
consumption goes down, a person has a clear picture of what he really needs. And along with this, he focuses on routine, habitual consumption.

Our research showed at the level of statistic significance $(\mathrm{p} \leq 0,05)$, that active consumers tend to reduce the range of protective (adaptive) behaviour strategies and in the meantime they increase constructive ones (ref. table 2).

TABLE II. INFLUENCE OF AGE PECULIARITIES ON CONSUMPTION STYLE

\begin{tabular}{|c|c|c|c|}
\hline \multirow[b]{2}{*}{$\begin{array}{c}\text { Style } \\
\text { of } \\
\text { consumer } \\
\text { behaviour }\end{array}$} & \multicolumn{3}{|c|}{ The results of one-way ANOVA test } \\
\hline & Periods of adulthood & $\begin{array}{c}\text { Average } \\
\text { values of } \\
\text { tendency } \\
\text { towards } \\
\text { choosing } \\
\text { style } \\
\end{array}$ & $\begin{array}{c}\text { Indicator } \\
\text { of power } \\
\text { of } \\
\text { influence }\end{array}$ \\
\hline \multirow{3}{*}{$\begin{array}{l}\text { Construct } \\
\text { ive } \\
\text { style }\end{array}$} & $\begin{array}{l}\text { Development of consumer } \\
\text { preferences (ages 17-23) }\end{array}$ & 17,6475 & \multirow{3}{*}{$\begin{array}{c}3,646 \\
\mathrm{p} \leq 0,005\end{array}$} \\
\hline & $\begin{array}{l}\text { Fixation of consumer } \\
\text { preferences (ages 23-45) }\end{array}$ & 18,9200 & \\
\hline & $\begin{array}{l}\text { Reduction of preferences } \\
\text { (ages 45-65) }\end{array}$ & 18,9603 & \\
\hline \multirow{3}{*}{$\begin{array}{l}\text { Adaptive } \\
\text { style }\end{array}$} & $\begin{array}{l}\text { Development of consumer } \\
\text { preferences (ages 17-23) }\end{array}$ & 8,7873 & \multirow{3}{*}{$\begin{array}{c}4,278 \\
\mathrm{p} \leq 0,005\end{array}$} \\
\hline & $\begin{array}{l}\text { Fixation of consumer } \\
\text { preferences (ages 23-45) }\end{array}$ & 7,4032 & \\
\hline & $\begin{array}{l}\text { Reduction of preferences } \\
\text { (ages 45-65) }\end{array}$ & 7,5175 & \\
\hline
\end{tabular}

The highest value of tendency to choose constructive style $(18,9603)$ is registered among respondents aged $45-65$. On the contrary, mean value of adaptive style rating is higher in the group of consumers under 23 years of age (8, 7873 with regard to a higher index $\mathrm{F}=4,278)$. At the stage of development of consumer preferences, young people are most often subject to the impulse purchase without taking into account theoretical frequency of pragmatic use of a newly bought thing, the use goods as means of raising their social status in the eyes of others and ways of controlling other people. It manifests itself in the desire to gain friendship or love through material resources.

\section{B. Influence of consumers' gender on consumer behaviour.}

Gender as a social construct also influences consumer styles. Woman's role in society is normally associated with the image of a shopper. The majority of goods are meant for women either directly or indirectly (in this case a man buys some goods seeking woman's attention or approval) (ref. table $3)$.

It is evident from the results that social stereotypes prove to be true in real life. Men appear to be inclined to adaptive style (average value of adaptive style among men is higher than that of women and is equal to 9, 391 while constructive style is more common among women $(19,2373))$.
TABLE III. INFLUENCE OF GENDER ON CONSUMER STYLES

\begin{tabular}{|l|l|l|l|}
\hline \multirow{2}{*}{$\begin{array}{c}\text { Style } \\
\text { of consumer } \\
\text { behaviour }\end{array}$} & \multicolumn{3}{|c|}{ The results of one-way ANOVA test } \\
\cline { 2 - 4 } & Sex & $\begin{array}{c}\text { Average values of } \\
\text { tendency towards } \\
\text { choosing style }\end{array}$ & $\begin{array}{c}\text { Indicator of } \\
\text { power } \\
\text { of influence }\end{array}$ \\
\hline \multirow{2}{*}{$\begin{array}{l}\text { Constructive } \\
\text { style }\end{array}$} & Male & 17,0991 & $\begin{array}{l}20,662, \\
\mathrm{p} \leq 0,000\end{array}$ \\
\cline { 2 - 4 } & Female & 19,2373 & $\begin{array}{l}23,650, \\
\mathrm{p} \leq 0,000\end{array}$ \\
\hline \multirow{2}{*}{$\begin{array}{l}\text { Adaptive } \\
\text { style }\end{array}$} & Male & 9,3391 & 7,1476 \\
\cline { 2 - 4 } & Female & &
\end{tabular}

The significance of this factor when identifying consumer style turned out the highest $(\mathrm{F}=23,650$ for adaptive style and $\mathrm{F}=20,662$ for constructive style). Similar tendencies occur both in case of realizing needs of affiliation or high social status and exercising control over other people.

\section{Values are the factor of tendency towards choosing a particular consumption style.}

In the context of the most significant values, one can talk of seven individual types. These values have an impact on the choice of consumption style (ref. table 4).

TABLE IV. INFLUENCE OF INDIVIDUAL'S VALUES ON CONSUMPTION STYLE

\begin{tabular}{|c|c|c|c|}
\hline \multirow[b]{2}{*}{$\begin{array}{c}\text { Style } \\
\text { of } \\
\text { consumer } \\
\text { behaviour }\end{array}$} & \multicolumn{3}{|c|}{ The results of one-way ANOVA test } \\
\hline & Individual types & $\begin{array}{c}\text { Average values } \\
\text { of tendency } \\
\text { towards } \\
\text { choosing style }\end{array}$ & $\begin{array}{c}\text { Indicator of } \\
\text { power } \\
\text { of influence }\end{array}$ \\
\hline \multirow{7}{*}{$\begin{array}{l}\text { Constructi } \\
\text { ve } \\
\text { style }\end{array}$} & Egocentric & 15,8750 & \multirow{7}{*}{$\begin{array}{c}6,064 \\
\mathrm{p} \leq 0,000\end{array}$} \\
\hline & Socio-centric & 19,8943 & \\
\hline & Pragmatic & 18,0270 & \\
\hline & Creative & 17,4769 & \\
\hline & Theoretical & 18,4773 & \\
\hline & Idealistic & 17,9111 & \\
\hline & Manipulative & 20,1000 & \\
\hline \multirow{7}{*}{$\begin{array}{l}\text { Adaptive } \\
\text { style }\end{array}$} & Egocentric & 10,3875 & \multirow{7}{*}{$\begin{array}{c}6,420 \\
\mathrm{p} \leq 0,000\end{array}$} \\
\hline & Socio-centric & 6,4357 & \\
\hline & Pragmatic & 8,4444 & \\
\hline & Creative & 9,0077 & \\
\hline & Theoretical & 7,9977 & \\
\hline & Idealistic & 8,4444 & \\
\hline & Manipulative & 6,4042 & \\
\hline
\end{tabular}

Possession of a given value is rather significant when it comes to manifestation of consumer behaviour. Socially orientated individuals are focused on finding constructive ways of co-operation with society. When searching and buying goods they are mainly ruled by their utility, reliability and performance and also ethic and aesthetic aspects. As for 
egocentric type, it is not the purchase itself that is important, the purchased item is the way to gain recognition of the society, avoid criticism, mockery or disapproval (egocentric type has got the highest index for the adaptive style $(10,3875)$ and the lowest index for the constructive style $(15,8750)$.

The conclusion that not only socio-centric type of consumer (average value is 6, 4357), but also people belonging to manipulative type (average value is 6, 4042) are inclined to use protective consumer strategies. Impulse purchase of goods or services can produce more stress and discomfort for the latter. They have communicative skills which make it possible for them to exercise control over other people, use then as a means of achieving their wishes. However, economic expenditures fall on the shoulders of their colleagues, partners or friends.

\section{Attitudes influence the choice of consumption style.}

Fixation on being ideal, perfect (perfectionism) makes people buy things which allow them to demonstrate their prettified image to other people (fashion plate). The results of statistical analysis prove this message: perfectionists have got the highest indicators of the tendency to adaptive style ( 9 , 9020).

TABLE V. INFLUENCE OF ATTITUDES ON CONSUMPTION STYLE

\begin{tabular}{|c|c|c|c|}
\hline \multirow{2}{*}{$\begin{array}{c}\text { Style } \\
\text { of } \\
\text { consumer } \\
\text { behaviour }\end{array}$} & \multicolumn{3}{|c|}{ The results of one-way ANOVA test } \\
\hline & Perfectionistic attitude & $\begin{array}{c}\text { Average values } \\
\text { of tendency } \\
\text { towards } \\
\text { choosing style }\end{array}$ & $\begin{array}{l}\text { Individu } \\
\text { al types }\end{array}$ \\
\hline \multirow{3}{*}{$\begin{array}{l}\text { Adaptive } \\
\text { style } \\
\text { (related } \\
\text { to status) }\end{array}$} & $\begin{array}{l}\text { Low level of } \\
\text { perfectionism }\end{array}$ & 6,8833 & \multirow{3}{*}{$\begin{array}{c}3,499, \\
\mathrm{p} \leq 0,005\end{array}$} \\
\hline & $\begin{array}{l}\text { High level of } \\
\text { perfectionism }\end{array}$ & 8,6485 & \\
\hline & $\begin{array}{l}\text { Perfectionistic } \\
\text { attitude }\end{array}$ & 9,9020 & \\
\hline \multirow{3}{*}{$\begin{array}{l}\text { Construct } \\
\text { ive } \\
\text { style }\end{array}$} & Low level of SPP & 19,1824 & \multirow{3}{*}{$\begin{array}{c}5,092, \\
\mathrm{p} \leq 0,005\end{array}$} \\
\hline & Average level of SPP & 18,4788 & \\
\hline & High level of SPP & 17,3820 & \\
\hline \multirow{3}{*}{$\begin{array}{l}\text { Adaptive } \\
\text { style }\end{array}$} & Low level of SPP & 7,1804 & \multirow{3}{*}{$\begin{array}{c}6,890, \\
\mathrm{p} \leq 0,005\end{array}$} \\
\hline & Average level of SPP & 7,8294 & \\
\hline & High level of SPP & 9,1674 & \\
\hline
\end{tabular}

This tendency is likely to manifest itself within the group of those consumers who have high figures of perfectionism oriented to others. People of that type are convinced that social surrounding doesn't meet their status, standards and ideals. The markers of that differentiation can be "exclusive" goods, brands or services which are not available to people from the surrounding community (or those who disapprove of their purchase).
The factor which affects greatly the choice of adaptive or constructive style is socially prescribed perfectionism (SPP). Consumers who take the society through the similar attitude have got the highest values of adaptive style (9, 1674 with a higher indicator $\mathrm{F}=6,890)$. Consumers convinced that the society sets the bar too high and that it is impossible for them to meet the standards of a "successive" person are more inclined to using protective strategies in their behaviour (ref. table 5).

The choice of goods, services and institutions for these individuals will to a great extent be determined by the opinion of the majority and the influence of promotion tools

\section{E. Specific aspects of thinking influence the choice of consumption style..}

Commitment to the intuitive vein leads to strengthening adaptive strategies. It is interesting to note that the more an individual is apt to cognitive perception of the world (thinking type) and making adequate decisions, the greater the possibility of manifestation of protective styles of consumption (average value is 8,8422 ).

TABLE VI. INFLUENCE OF SPECIFICS OF THINKING ON CONSUMPTION STYLE

\begin{tabular}{|c|c|c|c|}
\hline \multirow[b]{2}{*}{$\begin{array}{c}\text { Style } \\
\text { of } \\
\text { consumer } \\
\text { behaviour }\end{array}$} & \multicolumn{3}{|c|}{ The results of one-way ANOVA test } \\
\hline & $\begin{array}{l}\text { Specifics of thinking and } \\
\text { making decisions }\end{array}$ & $\begin{array}{c}\text { Average } \\
\text { values of } \\
\text { tendency } \\
\text { towards } \\
\text { choosing } \\
\text { style }\end{array}$ & $\begin{array}{l}\text { Individua } \\
\text { l types }\end{array}$ \\
\hline \multirow{3}{*}{$\begin{array}{l}\text { Adaptive } \\
\text { style }\end{array}$} & $\begin{array}{l}\text { Thinking type of decision- } \\
\text { making is accentuated feebly }\end{array}$ & 7,0586 & \multirow{3}{*}{$\begin{array}{c}5,035, \\
\mathrm{p} \leq 0,005\end{array}$} \\
\hline & $\begin{array}{l}\text { Thinking type of decision- } \\
\text { making is accentuated } \\
\text { moderately }\end{array}$ & 8,1202 & \\
\hline & $\begin{array}{l}\text { Thinking type of decision- } \\
\text { making is accentuated } \\
\text { intensely }\end{array}$ & 8,8422 & \\
\hline \multirow{3}{*}{$\begin{array}{l}\text { Construct } \\
\text { ive style }\end{array}$} & $\begin{array}{l}\text { Solving type (accentuated } \\
\text { feebly) }\end{array}$ & 17,5547 & \multirow{3}{*}{$\begin{array}{c}6,348, \\
\mathrm{p} \leq 0,005\end{array}$} \\
\hline & $\begin{array}{l}\text { Solving type (accentuated } \\
\text { moderately) }\end{array}$ & 18,0614 & \\
\hline & $\begin{array}{l}\text { Solving type (accentuated } \\
\text { intensely) }\end{array}$ & 19,5551 & \\
\hline
\end{tabular}

Solving (Decision-maker) type determines constructive styles (tendency to implementation of plans, completeness, structuredness enhances the possibility of using constructive styles of consumer behaviour). The average value on the scale of tendency towards constructive consumption styles is equal to 19,5551 .

\section{CONCLUSION}

The conducted research made it possible to consider the effect of different factors on forming consumer loyalty. We found a scientific evidence of the importance of human factors for describing and predicting consumer preferences. These 
factors aren't of equal importance for defining and predicting consumes' behaviour under making a purchase decision. It turned out that gender-role traits are the most crucial for forecasting consumer preferences. The other factors have nearly identical effect on behaviour: values, peculiarities of thinking and information perceiving, perfectionistic attitudes.

In the Volgograd and Astrakhan regions, constructive style is more frequent in women in their mid-twenties who think positively of their own personality; have an independent lifestyle; are focused on personal growth and interaction with other people. They possess sensorial way of making decisions (ability to exercise empathy, gift to choose goods taking into account values and interests of the person who these goods are meant for), aspiration for the balance in interacting with other people as well as completeness, preciseness and acting on a plan.

For consumers choosing constructive style of consumption, loyalty programme must include rational arguments (concerning performance attributes of goods, price/quality ratio). It is important to name the ways of getting additional bonuses through using more products (services) of the company.

As far as emotional arguments is concerned, they should point to the opportunity of self-development through using goods, keeping to consumption values, communicating within a certain group of consumers. Those sticking to that style will get interested in the loyalty programmes offering "consumption record," possibility of stockpiling of benefits. To register additional factors ("belonging to a social group" and "type of activity"), it is necessary to use methods of the "veiled elitism": invitation-only club events, personal informing about special offers and advertising promotions [15].

Men (especially aged under 24) focused on self-interest, success, prone to analysis and criticism prefer adaptive styles of behaviour. Their choice of a loyalty programme will depend on the existence in it of arguments demonstrating the potential for use of the products which confirm and make a point of their social status of a successful person, ability to make impression on other people. This type of consumers will be interested not in a discount on a bonus, but in opportunity of making a "quick" purchase without standing in a queue, getting priority service, individual order at any time convenient for them. Of a particular interest will also be special terms of making a purchase (service) from a partner company.

To sum up, while developing regional loyalty programmes it is necessary to take into account specific features of styles of consumer behaviour as well as requirements claimed by their adherents towards commercial offers of the companies. It means that laying down regional loyalty programmes should be performed with due consideration of both rational (related to functional properties of a product) and emotional arguments (opportunities for self-development through using goods, keeping to values, consuming, interacting within a group of consumers).

\section{References}

[1] Il'in V.I. "Consumer behavior" [Povedenie potrebitelei] Izd-vo Piter, 2003

[2] Kotler, F. "The fundamentals of marketing" [Osnovy marketinga]. Lyubertsy: Yurait, 2015. - $556 \mathrm{c}$.

[3] Mel'nikova O.T., Shirkov Yu.E., Folomeeva T.V. "Consumer behavior: theory and reality" [Potrebitel'skoe povedenie: teoriya i deistvitel'nost' ] Sotsial'naya psikhologiya v sovremennom mire M.:Aspekt Press, 2000.

[4] Posypanova O.S. "Ekonomicheskaya psikhologiya: psikhologicheskie aspekty povedeniya potrebitelei" [Economic psychology: the psychological aspects of consumer behavior]. Monografiya. Kaluga: Izdvo KGU im. K.E. Tsiolkovskogo, 2012. pp. 178.

[5] Stephen A. T. "The role of digital and social media marketing in consumer behavior" // Current Opinion in Psychology. 2016. T. 10. pp. $17-21$.

[6] Peterson R. A., Umesh U. N. "On the significance of statistically insignificant results in consumer behavior experiments "// Journal of the Academy of Marketing Science. 2018. T. 46. №. 1. pp. 81-91.

[7] Hayakawa H., Venieris Y. "Consumer interdependence via reference groups" // Behavioral Interactions, Markets, and Economic Dynamics. Springer, Tokyo, 2016. pp. 81-99.

[8] Mittal B. "Self-concept clarity: Exploring its role in consumer behavior" // Journal of Economic Psychology. 2015. T. 46. pp. 98-110.

[9] Rodríguez-Torrico P., Cabezudo R. S. J., San-Martín S. "Tell me what they are like and I will tell you where they buy. An analysis of omnichannel consumer behavior" // Computers in Human Behavior, 2017. T. 68. pp. 465-471.

[10] Kamaruddin A. R., Kamaruddin K. "Malay culture and consumer decision-making styles: an investigation on religious and ethnic dimensions" // Jurnal Kemanusiaan, 2017. T. 7. №. 2. pp. 37-50

[11] Akerlof, Dzh. "Spiritus animalis", How human psychology manages the economy and why it is important for world capitalism [«Spiritus animalis» Kak chelovecheskaya psikhologiya upravlyaet ekonomikoi i pochemu eto vazhno dlya mirovogo kapitalizma]. M. : OOO «Yunaited Press», 2010. pp. 273.

[12] Inshakov OV, Redkina O.Yu. "Interdisciplinary approach in modern historical, sociocultural and economic studies: on the scientific conference "Millennium of the Russian Truth - finding new meanings" " [Mezhdistsiplinarnyi podkhod $\mathrm{v}$ sovremennykh istoricheskikh, sotsiokul'turnykh i ekonomicheskikh issledovaniyakh: o nauchnoi konferentsii «Tysyacheletie Russkoi Pravdy - obretenie novykh smyslov»]. g. Volgograd, 21-22 aprelya $2016 \mathrm{~g} / /$ Vestnik VolGU. Seriya 4, Istoriya. Regionovedenie. Mezhdunarodnye otnosheniya. 2016. №3. pp.150-161.

[13] Tolstel M.S., Russkova E.G., Yalmaev R.A. "Regional economic integration under the conditions of globalization (the case of the eurasian economic union (EAEU))" [Regional'naya ehkonomicheskaya integraciya $\mathrm{V}$ usloviyah globalizacii (na primere Evrazijskogo Ehkonomicheskogo Soyuza (EAEHS))] // Vestnik Volgogradskogo gosudarstvennogo universiteta. Seriya 3: Ekonomika. Ekologiya. 2017. T. 19. № 3 (40). pp. 39-45.

[14] Timofeeva T.S. "Interrelation of styles of consumer behavior with perfectionist installation" [Vzaimosvyaz' stilei potrebitel'skogo povedeniya s perfektsionistskoi ustanovkoi]. // Izvestiya Dagestanskogo gosudarstvennogo pedagogicheskogo universiteta. Psikhologopedagogicheskie nauki, 2012. № 4 (21). pp. 5-10.

[15] Polusmakova N. S., Serova O. F., Chernova A. A. "Analysis and improvement of the typology of consumer loyalty programs" [ Analiz i sovershenstvovanie tipologii programm potrebitel'skoi loyal'nosti]. // Nauchno-tekhnicheskie vedomosti Sankt-Peterburgskogo gosudarstvennogo politekhnicheskogo universiteta. Ekonomicheskie nauki, 2017, T. 10. №. 